\title{
PENGARUH PENGAWASAN DAN KOMUNIKASI TERHADAP KINERJA PEGAWAI DI DINAS PENDIDIKAN KABUPATEN MUSI RAWAS
}

\author{
Surajiyo $^{1}$, Jepri $^{2}$ \\ ${ }^{1,2}$ Program Studi Manajemen, Universitas Bina Insan Lubuklinggau \\ Email : ${ }^{1}$ surajiyo@ univbinainsan.ac.id, ${ }^{2}$ jefryje13@gmail.com
}

\begin{abstract}
This study aims to determine the effect of supervision and communication on the performance of Musi Rawas District Education Office employees. The method used in this study is a quantitative method, and data collection techniques used in this study are questionnaires and observations. The number of respondents 53 people. Data analysis techniques using simple regression test, correlation coefficient, $t$ test, multiple regression test, determination test, and f test. The first hypothesis testing is the Supervision variable (X1) on employee performance $(Y)$ which shows that the calculation produces a coefficient of 22,830. With a sample size of 53 found $d f=(53-2)$ and at a significant level of 0.05, the t-table value was 1.675. With this result it can be said that Supervision has a significant effect on Employee Performance because $t$ arithmetic (22,830)> $t$ table (1,675). The second hypothesis testing is the Communication variable (X2) on employee performance $(Y)$ which shows that $t$ arithmetic produces a coefficient of 8,178. With a sample size of 53 found $d f=(53-2)$ and at a significant level of 0.05, the t-table value was 1.675. With these results it can be said that supervision has a significant effect on employee performance because t arithmetic $(8,178)>t$ table $(1,675)$. Then testing the third hypothesis found that the calculated $F$ value was 291,566> F table $=3.18$ and the significant level simultaneously sig $F$ was 0,000.
\end{abstract}

Keywords : Supervision, Communication, Employe Performance

\section{ABSTRAK}

Penelitian ini bertujuan untuk mengetahui pengaruh pengawasan dan komunikasi terhadap kinerja pegawai Dinas Pendidikan Kabupaten Musi Rawas. Metode yang digunakan penelitian ini adalah metode kuantitatif, dan teknik pengumpulan data yang digunakan dalam penelitian ini adalah kuesioner dan observasi. Jumlah responden 53 orang. Teknik analisis data menggunakan uji regresi sederhana, koefisien korelasi, uji t, uji regresi berganda, uji determinasi, dan uji f. Pengujian hipotesis pertama adalah variabel Pengawasan (X1) pada kinerja karyawan (Y) yang menunjukkan bahwa penghitungan menghasilkan koefisien 22.830. Dengan jumlah sampel 53 ditemukan $\mathrm{df}=(53-2)$ dan pada tingkat signifikan 0,05, nilai t tabel adalah 1,675. Dengan hasil ini dapat dikatakan bahwa Supervisi memiliki pengaruh yang signifikan terhadap Kinerja Karyawan karena $t$ hitung (22.830)> t tabel $(1,675)$. Pengujian hipotesis kedua adalah variabel Komunikasi (X2) pada kinerja karyawan (Y) yang menunjukkan bahwa t hitung menghasilkan koefisien 8,178. Dengan jumlah sampel 53 ditemukan $\mathrm{df}=(53-2)$ dan pada tingkat signifikan 0,05, nilai t tabel adalah 1,675. Dengan hasil ini dapat dikatakan bahwa Supervisi memiliki pengaruh yang signifikan terhadap Kinerja Karyawan karena t hitung $(8,178)>t$ tabel $(1,675)$. Kemudian pengujian hipotesis ketiga menemukan bahwa nilai $\mathrm{F}$ hitung adalah 291.566> $\mathrm{F}$ tabel $=3,18$ dan tingkat signifikan secara bersamaan sig $\mathrm{F}$ adalah 0,000.

Kata kunci : Pengawasan, Komunikasi, Kinerja Pegawai 


\section{PENDAHULUAN}

Setiap Organisasi dituntut untuk dapat mengoptimalkan Sumber Daya Manusia yang dimiliki baik organisasi swasta maupun organisasi pemerintahan. Organisasi pemerintahan yang bergerak di bidang Birokrasi harus memiliki Sumber Daya Manusia yang bermutu agar dapat memberikan pelayanan yang maksimal kepada masyarakat. Sumber Daya Manusia merupakan fakor yang paling penting dalam suatu organisasi ataupun perusahaan.

Setiap Organisasi dituntut untuk dapat mengoptimalkan dan mengelola Sumber Daya yang dimilki. Pengelolaan Sumber Daya Manusia dalam suatu organisasi tidak lepas dari faktor pegawai yang diharapkan dapat berprestasi sebaik mungkin agar terciptanya Sumber Daya yang unggul dalam mencapai tujuan suatu organisasi. Tujuan suatu organisasi akan sulit tercapai tanpa diikuti Sumber Daya yang berkualitas di dalamnya. Oleh sebab itu suatu Organisasi harus menitikberatkan terhadap peningkatan Sumber Daya Manusia agar dapat menjalankan tupoksinya dengan baik dalam mencapai tujuan organisasi.

Pegawai merupakan asset utama Organisasi yang memiliki peran yang sangat strategis sebagai pemikir, perencanaan, penggerak serta pengendali jalannya suatu roda Organisasi. Disamping mengharapkan kualitas seorang pegawai yang baik, organisasi ataupun instansi juga mengharapkan pegawai yang giat dan tekun serta berkeinginan mencapai hasil kerja yang maksimal. Melihat pentingnya pegawai dalam suatu Organisasi, maka perlu adanya pemimpin yang mampu untuk mengayomi serta memberi arahan kepada bawahan dengan baik supaya bisa menyelesaikan tugas yang di berikan dengan maksimal. Kualitas pegawai sangat ditentukan oleh peran seorang pemimpin dalam memberi masukan dan memberi arahan guna mengoptimalkan kinerja

Pegawai dalam melaksanakan tugas. Oleh sebab itu sudah sepatutnya seorang pemimpin melakukan evaluasi agar mengetahui tingkatan kinerja pegawai dalam hal pencapaian tujuan.

Menurut Bastian (dalam Fahmi, 2016:176), Kinerja adalah gambaran mengenai tingkat pencapaian pelaksanaan suatu kegiatan/ program/ kebijaksanaan dalam mewujudkan sasaran, tujuan, misi dan visi organisasi yang tertuang dalam perumusan skema strategis (strategic planning) suatu organisasi.

Setiap organisasi harus mampu mengukur setiap kinerja pegawainya karena hal ini merupakan salah satu faktor apakah perencanaan yang dilakukan selama ini dapat berjalan dengan baik atau tidak. Melalui kinerja kita dapat mengetahui kualitas dan kemampuan seorang pegawai. Organisasi memiliki kinerja yang baik apabila target yang ingin dicapai dapat terealisasi sesuai dengan perencanaan. Untuk mendapatkan kinerja yang baik maka pemimpin hendaknya memberikan pengawasan yang maksimal terhadap kinerja pegawai agar bisa bekerja dan melaksanakan tugas sesuai dengan rencana dan aturan-aturan yang ada. Faktor yang dapat meningkatkan Kinerja antara lain Pengawasan dan Komunikasi. Menurut G.R. Terry (dalam Fahmi, 2017:51), Pengawasan dapat didefinisikan sebagai proses penentuan, apa yang harus dicapai yaitu standar, apa yang sedang dilakukan yaitu pelaksanaan, menilai pelaksanaan dan apabila perlu dilakukan perbaikan-perbaikan, sehingga pelaksanaan sesuai dengan rencana yaitu selaras dengan standar. Pengawasan kepada seorang pegawai memang sangat diperlukan dalam suatu organisasi dalam upaya peningkatan kinerja pegawai. Pengawasan yang dilakukan bertujuan untuk mengetahui apakah pegawai dalam melakukan pekerjaannya sesuai dengan rencana, perintah, tujuan ataupun kebijakan yang telah ditentukan. Dengan pengawasan seorang pemimpin akan tahu sebatas mana kinerja pegawai dalam menyelesaikan tugas yang diberikan. Apabila pekerjaan belum sesuai maka dapat dibetulkan dan apabila 
sudah sesuai maka harus ditingkatkan. Dengan demikian dengan adanya pengawasan maka dapat meningkatkan kemampuan kerja pegawai dalam mencapai tujuan Organisasi.

Tujuan utama dari pengawasan adalah mengusahakan agar sesuatu yang telah direncanakan sedari awal dapat menjadi kenyataan. Oleh karenanya agar sistem pengawasan dapat berjalan dengan baik, maka sistem pengawasan harus dengan segera melaporkan penyimpangan yang ada agar dapat ditindak secepat mungkin supaya pengawasan yang dilakukan dapat memberi energi positif terhadap produktivitas pegawai. Selain memberikan pengawasan, seorang pemimpin harus menciptakan iklim Organisasi yang baik dalam suatu Organisai. Komunikasi sangat berperan aktif dalam terciptanya iklim organisasi yang baik. Apabila komunikasinya baik maka akan memberikan kenyamanan terhadap pegawai dalam menyelesaikan suatu pekerjaan, karena pekerjaan mereka biasanya saling berhubungan dengan pegawai-pegawai lainnya. Komunikasi yang dimaksudkan disini ialah komunikasi atasan dengan bawahan, bawahan dengan atasan maupun antar sesama pegawai.

Selain pengawasan, komunikasi juga memiliki peran dalam meningkatkan kinerja. Menurut Cooley (dalam Feriyanto dan Triana, 2015), Komunikasi adalah suatu mekanisme hubungan antar manusia dilakukan dengan mengartikan simbol secara lisan dan membacanya melalui ruang dan menyimpan dalam waktu. Dengan kata lain komunikasi adalah suatu proses pengelolaan data atau informasi dengan menyampaikan kepada orang lain baik secara langsung ataupun tidak langsung. Komunikasi yang baik dalam suatu organisasi akan memberikan kenyaman kepada pegawai dalam menyelesaikan suatu pekerjaan. Adanya komunikasi yang baik maka informasi yang diberikan dapat tersampaikan dan dikelola dengan baik oleh penerima informasi. Komunikasi merupakan proses yang vital dalam suatu Organisasi, karena komunikasi digunakan pada saat perencanaan, koordinasi, pengendalian serta proses-proses lainnya. Dengan demikian komunikasi yang efektif sangat dibutuhkan supaya dapat meningkatkan kinerja pegawai dalam pencapaian tujuan organisasi.

Pengawasan dan komunikasi adalah faktor yang dapat meningkatkan kinerja pegawai. Pemberian pengawasan yang maksimal serta komunikasi yang efektif dalam suatu organisasi akan mempermudah organisasi tersebut dalam hal pencapaian tujuan. Apabila suatu organisasi belum menciptakan budaya organisasi yang baik seperti dengan adanya pengawasan yang rutin dan jalinan komunisasi yang efektif, maka organisasi tersebut akan menimbulkan berbagai macam permasalahan yang dapat menjadi penghambat dalam melaksanakan aktivitas kerja untuk pencapaian tujuan. Hal ini seperti yang terjadi pada Dinas Pendidikan Kabupaten Musi Rawas yang masih kurangnya sistem pengawasan dan komunikasi yang belum efektif.

Dinas Pendidikan Kabupaten Musi Rawas ialah instansi pemerintahan yang bergerak di bidang pendidikan dan beralamat di jalan Lintas Sumatera KM 12,5 Muara Beliti Kecamatan Muara Beliti Kabupaten Musi Rawas. Dinas Pendidikan Kaupaten Musi Rawas memiliki tugas dan fungsi untuk melaksanakan fungsi pemerintahan daerah bidang pendidikan berdasarkan azas otonomi dan tugas pembantuan serta melaksanakan tugas-tugas lain yang diberikan oleh bupati sesuai dengan bidang tugasnya.

Setelah peneliti melakukan survey di Dinas Pendidikan Kabupaten Musi Rawas, ditemukan permasalahan-permasalahan yang berkaitan dengan kinerja pegawai diantaranya: kurangnya tanggung jawab pegawai dalam menyelesaikan tugas seperti masih adanya surat masuk yang hilang, pegawai sering menunda pekerjaanya sehingga tugas belum selesai tepat waktu. Selanjutnya fenomenafenomena yang berkaitan dengan pengawasan ialah masih adanya pegawai yang tidak berada di meja kerja saat jam kerja dan kurangnya 
pengawasan dari pimpinan dilihat dari pegawai yang sering terlambat pada saat apel pagi. Kemudian fenomena yang berkaitan dengan komunikasi yaitu belum terciptanya komunikasi yang baik anatar pegawai karena sering menggunakan bahasa daerah dan masih kurangnya hubungan kekeluargaan antar pegawai.

Berdasarkan penjelasan di atas menunjukkan bahwa pengawasan dan komunikasi memiliki pengaruh terhadap kinerja dalam mencapai suatu tujuan. Instansi pemerintah harus senantiasa memberikan pengawasan agar pegawai dapat bekerja sesuai dengan standar yang telah ditetapkan, serta manajemen komunikasi yang baik supaya informasi yang disampaikan dapat tersalurkan dengan maksimal sehingga pekerjaan akan terlaksana sesuai dengan yang direncanakan. Dengan demikian maka penulis tertarik melakukan penelitian dengan judul

"PENGARUH PENGAWASAN DAN KOMUNIKASI TERHADAP KINERJA PEGAWAI DI DINAS PENDIDIKAN KABUPATEN MUSI RAWAS".

\section{TINJAUAN PUSTAKA}

\subsection{Kinerja}

Menurut Fahmi (2016:176), kinerja adalah hasil yang diperoleh oleh suatu organisasi baik organisasi tersebut bersifat profit oriented dan non profit oriented yang dihasilkan selama satu periode tertentu.

Selanjutnya menurut Bintaro dan Daryanto (2017:109), kinerja adalah prestasi kerja atau hasil kerja baik kualitas maupun kuantitas yang dicapai sumber daya manusia per satuan periode waktu dalam melaksanakan tugas kerjanya sesuai dengan tanggung jawab yang diberikan kepadanya.

Menurut Bintaro dan Daryanto (2017:109), faktor-faktor yang mempengaruhi kinerja diantaranya sebagai berikut:

1. Fasilitas Kantor

Fasilitas kantor merupakan sarana yang menunjang seseorang karyawan untuk melakukan aktifitas kerjanya dengan baik dan apabila perusahaan anda tidak dapat memberikan fasilitas yang memadai, tentu saja hal ini akan menurunkan kinerja kerja karyawan anda. Jika anda adalah seorang star-up yang baru saja memulai usaha, akan lebih baik jika hal ini dijelaskan terlebih dahulu di awal perekrutan karyawan sehingga mereka tahu dan siap beekrja dengan kondisi fasilitas yang kurang memadai.

2. Lingkungan Kerja

Lingkungan kerja merupakan faktor yang sangat penting untuk anda perhatikan, karena hampir $80 \%$ karyawan resign jika lingkungan kerja mereka tidak baik. Lingkungan kerja yang baik memilki ruang kerja yang cuckup luas, penerangan yang sempurna dan temperatur udara yang sesuai dengan luas ruangan kerja karayawan anda. Jika ada salah satu fasilitas tersebut yang rusak, langsung segera diperbaiki agar kinerja kerja mereka tidak menurun dan mereka tetap nyaman dalam melakukan aktifitas kerja mereka sehari-hari.

3. Prioritas Kerja

Berikan prioritas kerja yang jelas. Karyawan akan merasa kebingungan jika anda memberikan banyak tugas kepada mereka tetapi tidak memberikan skala prioritas yang jelas, kemudian biarkan mereka mengerjakan pekerjaannya satu demi satu dengan timline yang sudah anda tentukan dan jangan menambahkan tugas yang lain sebelum pekerjaan tersebut diselesaikan, jika memang ada pekerjaan penting yang harus anda berikan karyawan, maka anda harus menggeser deadline pekerjaan yang sebelumnya dikerjaakan, supaya karyawan anda dapat beekrja dengan tenang dan tidak didesak oleh waktu.

4. Supportive Boss

Sebagai atasan yang baik anda harus mau "mendengarkan" pendapat dan pemikiran karyawan anda. Berikan dukungan kepada mereka untuk mengemukakan pendapat 
dan ide-ide baru pada saat meeting, ajak mereka untuk "terlibat" dalam proyek yang sedang anda kerjakan. Anda juga harus memberikan ruang kepda mereka untuk belajar dan berkreasi pada bidang yang mereka minati supaya mereka dapat terus mengasah ilmunya, sebab jika suatu saat jika anda membutuhkan skill tersebut anda bisa menggunakan tenaga mereka tanpa harus merekrut karyawan baru dan tentu saja hal ini akan menguntungkan perusahaan anda.

5. Bonus

Sebagian besar karyawan akan bekerja dengan senang hati bila pekerjaan yang mereka kerjaan dihargai oleh perusahaan. Penghargaan terhadap karyawan bisa dimulai dari hal yang sederhana seperti pujian dari atasan atau bahkan berupa bonus. Bonus ini dapat anda berikan kepada karyawan anda yang memang benar-benar mampu bekerja dengan baik sesuai dengan yang anda harapkan. Pemberian penghargaan tersebut ada baiknya jika disaksikan oleh karyawan anda yang lain, tujuannya untuk memicu rasa kompetisi agar mereka dapat bekerja lebih baik lagi.

\subsection{Pengawasan}

Menurut Hasibuan (dalam Busro, 2018:142), pengawasan adalah kegiatan untuk mengendalikan seluruh karyawan, agar menaati peraturan-peraturan perusahaan dan bekerja sesuai rencana. Dalam definisi ini ditegaskan tiga hal yaitu: pengendalian, pengukuran kinerja karyawan, penaatan seluruh aturan, dan pencapaian rencana.

Selanjutnya menurut Feriyanto dan Triana (2015:63), pengawasan merupakan pengawasan merupakan fungsi manajerial yang keempat setelah perencanaan, pengorganisasian, dan pengarahan. Sebagai salah satu fungsi manajemen, mekanisme pengawasan di dalam suatu organisasi memang mutlak diperlukan. Pelaksanaan suatu rencana atau program tanpa diiringi dengan suatu sistem pengawasan yang baik dan

berkesinambungan, jelas akan mengakibatkan lambatnya atau bahkan tidak tercapainya sasaran dan tujuan yang telah ditentukan

Indikator pengawasan menurut

Handoko (2015:373) sebagai berikut:

1. Akurat, informasi tentang pelaksanaan kegiatan harus akurat karena bila tidak akurat maka dari sistem pengawasan dapat menyebabkan organisasi mengambil tindakan koreksi yang keliru atau bahkan menciptakan masalah yang sebenarnya tidak ada.

2. Tepat waktu, informasi harus dikumpulkan, disamakan dan dievaluasi secepatnya bila kegiatan perbaikan harus segera dilakukan.

3. Terpusat pada titik-titk pengawasan strategi, sistem pengawasan harus memusatkan perhatian pada bidangbidang di mana penyimpanganpenyimpangan dari standar paling sering terjadi atau yang akan mengakibatkan kerusakan paling fatal.

4. Objektif dan menyeluruh, informasi harus mudah dipahami dan bersifat objektif serta lengkap.

\subsection{Komunikasi}

Menurut Mangkunegara (2017:145), komumikasi dapat diartikan sebagai proses pemindahan suatu informasi, ide, pengertian dari seseorang kepada orang lain dengan harapan orang lain tersebut dapat menginterprestasikannya sesuai dengan tujuan yang dimaksud.

Selanjutnya menurut Feriyanto dan Triana (2015:154), komunikasi adalah suatu proses dimana sesorang atau beberapa orang, kelompok, organisasi, dan masyrakat menciptakan dan menggunakan informasi agar terhubung dengan lingkungan dan orang lain. Indikator komunikasi dalam penelitian ini menurut Nurhasanah (2010:43):

1. Kredibilitas

Kredibilitas (kredibility) terdapat dan berpengaruh pada sumber atau 


\begin{abstract}
komunikator. Kredibilitas komunikasi sangat mempengaruhi keberhasilan proses komunikasi, karena hal ini mempengaruhi tingkat kepercayaan sasaran atau komunikasi terhadap pesan yang disampaikan.
\end{abstract}

2. Isi Pesan

Pesan yang disampaikan hendaknya mengandung isi yang bermanfaat bagi sasaran. Hasil komunikasi akan lebih baik jika isi pesan besar manfaatnya bagi kepentingan sasaran.

3. Kesesuaian dengan Kepentingan Sasaran Kesesuaian dengan kepentingan sasaran terdapat dan berperan pada pesan. Pesan yang disampaikan harus berhubungan dengan kepentingan sasaran

4. Kejelasan

Kejelasan (clarity), terdapat dan berperan pada pesan. Kejelasan pesan yang disampaikan sangat berpengaruh terhadap efektivitas komunikasi. Pesan yang kurang jelas dapat ditafsirkan berbeda oleh komunikan sehingga antara komunikan dan komunikator dapat berbeda persepsi tentang pesan yang disampaikan.

\subsection{Kerangka Pemikiran}

Menurut Uma Sekaran dalam Sugiyono (2018:128), Kerangka berfikir merupakan model konseptual tentang bagaimana teori berhubungan dengan berbagai faktor yang telah diidentifikasikan sebagai maslalah penting. Kerangka pemikiran ini merupakan penjelasan sementara terhadap gejala-gejala yang menjadi objek permasalahan. Kerangka pemikiran ini dibuat dengan mengambil indikator indikator masingmasing variabel. Adapaun kerangka pemikiran dalam penelitian ini adalah :

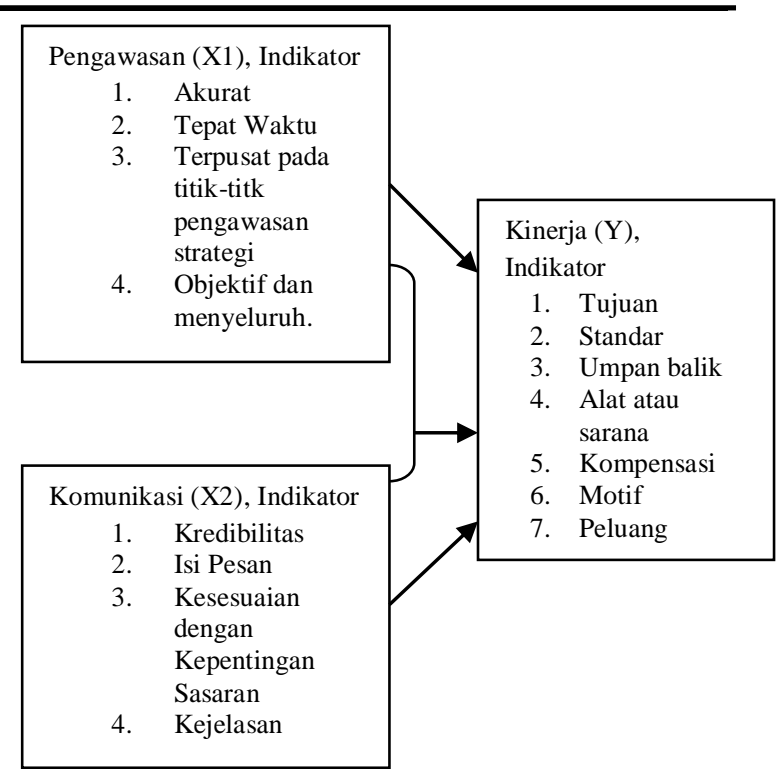

Gambar 1

Kerangka Pemikiran

\subsection{Hipotesis}

Adapun hipotesis di penelitian ini sebagai berikut:

1. Terdapat pengaruh signifikan antara Pengawasan terhadap Kinerja Pegawai pada Dinas Pendidikan Kabupaten Musi Rawas.

2. Terdapat pengaruh signifikan antara Komunikasi terhadap Kinerja Pegawai pada Dinas Pendidikan Kabupaten Musi Rawas.

3. Terdapat pengaruh signifikan antara Pengawasan dan Komunikasi terhadap Kinerja Pegawai pada Dinas Pendidikan Kabupaten Musi Rawas,

\section{METODOLOGI PENELITIAN}

\subsection{Desain Penelitian}

Menurut Sujarweni (2015:71), Desain penelitian adalah pedoman atau prosedur serta teknik dalam perencanaan penelitian yang berguna sebagai panduan untuk membangun strategi yang menghasilkan model atau blue print penelitian. Terdapat tiga desain penelitian yang paling umum digunakan, yaitu tipe deskriptif, komparatif, dan asosiatif. 


\subsection{Populasi dan Sampel}

Menurut Sugiyono (2018:148),

Populasi adalah wilayah generalisasi yang terdiri atas: obyek/subyek yang mempunyai kuantitas dan karakteristik tertentu yang ditetapkan oleh peneliti untuk dipelajari dan kemudian ditarik kesimpulannya. Jadi populasi bukan hanya orang, tetapi juga obyek dan benda-benda alam yang lain.Dalam penelitian ini jumlah populasi di Dinas Pendidikan Kabupaten Musi Rawas adalah 53 orang (48 PNS dan 5 Honorer) yang terdiri dari 1 orang kepala dinas, 3 orang Kabid, 2 orang Kasubag, 9 orang Kasi dan 38 Fungsional Umum.

Menurut Sugiyono (2018:149), sampel adalah bagian dari jumlah dan karakteristik yang dimiliki oleh populasi tersebut. Bila populasi besar, dan peneliti tidak mungkin mempelajari semua yang ada pada populasi, misalnya karena keterbatasan dana, tenaga dan waktu, maka peneliti dapat menggunakan smapel yang diambil dari populasi itu. Apa yang dipelajari dari sampel itu, kesimpulannya akan dapat diberlakukan untuk populasi. Untuk itu, sampel yang diambil dari populasi harus betul-betul representatif (mewakili). Teknik penentuan dalam sampel ini adalah dengan menggunakan sampel jenuh. Menurut Sugiyono (2013:122), sampling jenuh adalah teknik penentuan sampel bila semua anggota populasi digunakan sebagai sampel. Jadi jumlah sampel dalam penelitian ini ialah 53 orang pegawai.

\section{HASIL DAN PEMBAHASAN}

\subsection{Hasil}

\section{Karakteristik Responden}

a. Jenis Kelamin

Sebagian besar responden ialah berjenis kelamin laki-laki yaitu sebanyak 28 orang atau $52,8 \%$ dan sisanya berjenis kelamin perempuan sebanyak 25 orang atau $47,2 \%$.

b. Umur

Responden dalam penelitian ini yang berumur 21-30 tahun sebanyak 7 orang atau $13,2 \%$, yang berumur 31 -
40 tahun sebanyak 10 orang atau $18,9 \%$, yang berumur $41-50$ tahun sebanyak 22 orang atau $41,5 \%$, dan yang berumur $>51$ tahun sebanyak 14 orang atau $26,4 \%$.

c. Pendidikan

Responden dalam penelitian ini yang berpendidikan terakhir SMA sebanyak 17 orang atau $32,1 \%$, D3 sebanyak 2 orang atau $3,8 \%, \mathrm{~S} 1$ sebanyak 27 orang atau $50,9 \%$, dan S2 sebanyak 7 orang atau 13,2\%.

\section{Hasil Pengujian Validitas}

Hasil pengolahan data uji validitas instrumen Pengawasan, Komunikasi dan Kinerja dari 10 pertanyaan dengan jumlah responden sebanyak 20 orang, didapatkan setiap nilai korelasi per item terhadap total itemnya lebih besar dari nilai $r$ tabel sebesar 0,444, maka setiap pertanyaan untuk variabel Pengawasan, Komunikasi dan Kinerja dapat dikatakan valid atau sah.

\section{Hasil Pengujian Reliabilitas}

Bahwasannya Cronbach's Alpha setiap variabel lebih dari 0,444 dengan demikian dapat disimpulkan bahwa konstruk pertanyaan dalam kuesioner yang merupakan dimensi Pengawasan, Komunikasi dan Kinerja adalah Reliabel.

\section{Koefesien Korelasi}

Hasil Koefesien Korelasi pengawasan terhadap kinerja di peroleh angka $\mathrm{R}$ sebesar 0,954. Hal ini menunjukkan bahwa variabel Pengawasan (X1) terhadap Kinerja (Y) memiliki hubungan yang sangat kuat. Sedangkan arah hubungan adalah positif karena nilai $\mathrm{R}$ positif.

Hasil koefesien korelasi komunikasi terhadap kinerja di peroleh angka $\mathrm{R}$ sebesar 0,753. Hal ini menunjukkan bahwa variabel Komunikasi (X2) terhadap Kinerja (Y) memiliki 
hubungan yang kuat. Sedangkan arah hubungan adalah positif karena nilai $R$ positif.

\section{Hasil Uji t}

Uji t pengawasan terhadap kinerja menunjukkan $t_{\text {hitung }}$ menghasilkan koefesien sebesar 22,830. Dengan jumlah sampel 53 ditemukan $\mathrm{df}=53(53-2)$ dan pada taraf signifikansi sebesar 0,05 , nilai $\mathrm{t}_{\text {tabel }}$ sebesar 1,675. Dengan hasil ini dapat dikatakan bahwa Pengawasan memiliki pengaruh signifikan terhadap Kinerja karena $(22,830)>t_{\text {tabel }}(1,675)$.

Uji t komunikasi terhadap kinerja menunjukkan $t_{\text {hitung }}$ menghasilkan koefesien sebesar 8,178. Dengan jumlah sampel 53 ditemukan $\mathrm{df}=53(53-2)$ dan pada taraf signifikansi sebesar 0,05 , nilai $\mathrm{t}_{\text {tabel }}$ sebesar 1,675. Dengan hasil ini dapat dikatakan bahwa Pengawasan memiliki pengaruh signifikan terhadap Kinerja karena $(8,178)>t_{\text {tabel }}(1,675)$.

\section{Koefesien Determinasi}

Dari hasil koefesien determinasi diperoleh nilai koefesien determinasi sebesar $R^{2}=0,960$ atau $96,0 \%$, artinya besarnya hubungan Pengawasan (X1) dan Komunikasi (X2) terhadap Kinerja (Y) sebesar $96,0 \%$, sedangkan sisanya $4,0 \%$ dipengaruhi oleh variabel lain yang tidak diamati dalam penelitian ini.

\section{Uji f}

Nilai $F_{\text {hitung }}$ yang diperoleh adalah sebesar 291,566 dengan tingkat signifikansi 0,000. Dimana jika $F_{\text {hitung }}>$ $\mathrm{F}_{\text {tabel }}$ maka Ho di tolak dan Ha diterima. Sebaliknya jika $F_{\text {hitung }}<\mathrm{F}_{\text {tabel }}$ maka Ho diterima dan Ha ditolak. Pada penelitian ini ternayata $F_{\text {hitung }}(291,566)>F_{\text {tabel }}$ $(3,18)$, artinya Ho ditolak dan $\mathrm{Ha}$ diterima. Hal ini menunjukkan ada pengaruh yang signifikan antara variabel Pengawasan (X1) dan variabel Komunikasi (X2) terhadap Kinerja
Hasil uji korelasi sederhana menunjukkan bahwa terdapat hubungan yang positif dan signifikan antara variabel Pengawasan dan Komunikasi terhadap Kinerja, karena hasil hitung uji korelasi lebih besar daripada $r$ tabel. Hubungan antara variabel bebas dan variabel terikat diketahui dengan melakukan uji regresi sederhana dan uji regresi berganda.

Hasil uji regresi sederhana menunjukkan bahwa secara terpisah terjadi hubungan atau pengaruh yang positif dari masing-masing variabel bebas terhadap variabel terikatnya. Selain menggunakan uji regeresi sederhana juga menggunakan ui regresi berganda. Hasil uji regresi berganda menunjukkan makna yang sama bahwa jika dua variabel bebas yaitu Motivasi dan Komunikasi secara bersamaan ditingkatkan atau mengalami peningkatan akan mempengaruhi peningkatan variabel terikatnya.

\subsection{Pembahasan}

1. Pengaruh Pengawasan terhadap Kinerja

Dari hasil perhitungan regresi linier sederhana, diperoleh nilai $b_{1}=0,970$ sedangkan nilai $\mathrm{a}=1,838$. Kemudian nilai tersebut dimasukkan ke dalam persamaan regresi linier sederhana yaitu $\mathrm{Y}=1,838+$ $0,970 \quad \mathrm{X}_{1}$ yang artinya jika variabel Pengawasan (X1) tidak ada perubahan atau nilainya nol maka nilai variabel Kinerja $(\mathrm{Y})$ sebesar 1,838.

Koefesien regresi Pengawasan (X1) sebesar $b_{1}=0,970$ menyatakan bahwa setiap peningkatan Pengawasan (X1) sebesar satu satuan maka hal tersebut akan meningkatkan Kinerja (Y) sebesar 0,970. Sebaliknya setiap penurunan Pengawasan (X1) sebesar satu satuan maka hal tersebut akan menurunkan Kinerja (Y) sebesar 0,970.

Nilai koefesien korelasi diperoleh angka $\mathrm{R}$ sebesar 0,954. Hal ini menunjukkan bahwa variabel Pengawasan 
(X1) terhadap Kinerja (Y) memiliki hubungan yang sangat kuat. Sedangkan arah hubungan adalah positif karena nilai $\mathrm{R}$ positif.

Dari hasil perhitungan uji $\mathrm{t}$ diketahui hasil $t_{\text {hitung }}$ menunjukkan bahwa variabel Pengawasan (X1) mempunyai nilai $t_{\text {hitung }}$ sebesar 22,830 lebih besar dibandingkan dengan nilai $t_{\text {tabel }}$ pada taraf nyata sebesar 1,675 . Jumlah sampel 53 ditemukan $\mathrm{df}=(53-2)$ dan taraf signifikansi sebesar 0,05. Dari data tersebut terdapat bahwa $t_{\text {hitung }}$ lebih besar dari $t_{\text {tabel }}\left(t_{\text {hitung }}>t_{\text {tabel }}\right.$ ) maka dapat dikatakan bahwa variabel Pengawasan (X1) berpengaruh signifikan terhadap Kinerja (Y). Selanjutnya hasil penelitian ini didukung oleh penelitian yang dilakukan oleh Rocmad Fajar Darmanto (2018) yang mengemukakan bahwa variabel Pengawasan (X1) terbukti memiliki pengaruh yang kuat terhadap variabel Kinerja (Y) yaitu sebesar 0,297. Variabel Komunikasi (X2) terbukti memiliki pengaruh yang kuat terhadap variabel Kinerja (Y) yaitu sebesar 0,287. Variabel Motivasi Kerja (X3) terbukti mempunyai pengaruh yang kuat terhadap variabel Kinerja (Y) yaitu sebesar 0,445. Secara simultan atau bersama-sama terdapat pengaruh positif antara variabel Pengawasan (X1), variabel Komunikasi (X2), dan variabel Motivasi Kerja (X3) terhadap variabel Kinerja (Y), dengan perolehan nilai sebesar 0,588 atau $58,8 \%$. Sehingga dapat disimpulkan bahwa peningkatan kerja 58,8\% dipengaruhi oleh variabel Pengawasan, variabel Komunikasi dan variabel Motivasi Kerja.

Kemudian didukung penelitian dari Dinda Shara Harum Febriani (2018) yang menyatakan bahwa Metode yang digunakan ialah analisis regeresi berganda. Teknik analisis data menggunakan uji reabilitas, uji validitas, uji asumsi klasik, uji koefesien determinasi, uji $\mathrm{F}$, uji t, dan uji tunggal untuk menguji efek mediasi. Diperoleh nilai koefesien determinasi $\left(\mathrm{R}^{2}\right)$ sebesar 0,585 yang berrati bahwa $58,5 \%$ variasi dari komitmen organisasi dapat dijelaskan oleh variabel pengawasan, motivasi kerja, dan komunikasi interpersonal. Sedangkan sisanya sebesar $41,5 \%$ dapat diejlaskan oleh variabel lain diluar penelitian ini. Selanjutnya, nilai $\mathrm{F}$ pada struktur I yaitu 24,038 dengan tingkat signifikansi 0,000, dan pada struktur II yaitu 17,467 dengan tingkat signifikansi 0,000 . Hasil penelitian ini menunjukkan bahwa pengawasan memiliki pengaruh positif dan dampak signifikan terhadap komitmen organisasi, motivasi kerja berpengaruh positif dan signifikan berdampak pada komitmen organisasi, komunikasi interpersonal berpengaruh positif dan signifikan berdampak pada komitmen organisasi, komitmen organisasi berpengaruh positif dan signifikan terhadap kinerja karyawan, pengawasan berpengaruh positif dan signifikan terhadap kinerja karyawan motivasi kerja tidak berpengaruh positif dan signifikan terhadap kinerja karyawa, dan komunikasi interpersonal memiliki pengaruh positif dan signifikan terhadap kinerja karyawan.

\section{Pengaruh Komunikasi terhadap Kinerja}

Dari hasil perhitungan regresi linier sederhana, diperoleh nilai $\mathrm{b}_{2}=0,738$ sedangkan nilai $\mathrm{a}=8,820$. Kemudian nilai tersebut dimasukkan ke dalam persamaan regresi linier sederhana yaitu $\mathrm{Y}=8,820+$ $0,738 \quad \mathrm{X}_{2}$ yang artinya jika variabel Komunikasi (X2) tidak ada perubahan atau nilainya nol maka nilai variabel Kinerja (Y) sebesar 8,820.

Koefesien regresi Komunikasi (X2) sebesar $b_{2}=0,738$ menyatakan bahwa setiap peningkatan Komunikasi (X2) sebesar satu satuan maka hal tersebut akan meningkatkan Kinerja (Y) sebesar 0,738. Sebaliknya setiap penurunan Komunikasi 
(X2) sebesar satu satuan maka hal tersebut akan menurunkan Kinerja (Y) sebesar 0,738 .

Nilai koefesien korelasi diperoleh angka $\mathrm{R}$ sebesar 0,753. Hal ini menunjukkan bahwa variabel Komunikasi (X2) terhadap Kinerja (Y) memiliki hubungan yang kuat. Sedangkan arah hubungan adalah positif karena nilai $\mathrm{R}$ positif.

Dari hasil perhitungan uji t diketahui hasil $t_{\text {hitung }}$ menunjukkan bahwa variabel Komunikasi (X2) mempunyai nilai $t_{\text {hitung }}$ sebesar 8,178 lebih besar dibandingkan dengan nilai $t_{\text {tabel }}$ pada taraf nyata sebesar 1,675. Jumlah sampel 53 ditemukan df $=$ (53 - 2) dan taraf signifikansi sebesar 0,05.

Dari data tersebut terdapat bahwa $t_{\text {hitung }}$ lebih besar dari $t_{\text {tabel }}\left(t_{\text {hitung }}>t_{\text {tabel }}\right)$ maka dapat dikatakan bahwa variabel Komunikasi (X2) berpengaruh signifikan terhadap Kinerja (Y). Selanjutnya hasil penelitian ini didukung oleh penelitian yang dilakukan oleh Rocmad Fajar Darmanto (2018) yang mengemukakan bahwa variabel Pengawasan (X1) terbukti memiliki pengaruh yang kuat terhadap variabel Kinerja (Y) yaitu sebesar 0,297. Variabel Komunikasi (X2) terbukti memiliki pengaruh yang kuat terhadap variabel Kinerja (Y) yaitu sebesar 0,287. Variabel Motivasi Kerja (X3) terbukti mempunyai pengaruh yang kuat terhadap variabel Kinerja $(\mathrm{Y})$ yaitu sebesar 0,445 . Secara simultan atau bersama-sama terdapat pengaruh positif antara variabel Pengawasan (X1), variabel Komunikasi (X2), dan variabel Motivasi Kerja (X3) terhadap variabel Kinerja (Y), dengan perolehan nilai sebesar 0,588 atau $58,8 \%$. Sehingga dapat disimpulkan bahwa peningkatan kerja 58,8\% dipengaruhi oleh variabel Pengawasan, variabel Komunikasi dan variabel Motivasi Kerja.

Kemudian didukung penelitian dari Dinda Shara Harum Febriani (2018) yang menyatakan bahwa Metode yang digunakan ialah analisis regeresi berganda. Teknik analisis data menggunakan uji reabilitas, uji validitas, uji asumsi klasik, uji koefesien determinasi, uji $\mathrm{F}$, uji $\mathrm{t}$, dan uji tunggal untuk menguji efek mediasi. Diperoleh nilai koefesien determinasi $\left(\mathrm{R}^{2}\right)$ sebesar 0,585 yang berrati bahwa $58,5 \%$ variasi dari komitmen organisasi dapat dijelaskan oleh variabel pengawasan, motivasi kerja, dan komunikasi interpersonal. Sedangkan sisanya sebesar $41,5 \%$ dapat diejlaskan oleh variabel lain diluar penelitian ini. Selanjutnya, nilai $\mathrm{F}$ pada struktur I yaitu 24,038 dengan tingkat signifikansi 0,000, dan pada struktur II yaitu 17,467 dengan tingkat signifikansi 0,000 . Hasil penelitian ini menunjukkan bahwa pengawasan memiliki pengaruh positif dan dampak signifikan terhadap komitmen organisasi, motivasi kerja berpengaruh positif dan signifikan berdampak pada komitmen organisasi, komunikasi interpersonal berpengaruh positif dan signifikan berdampak pada komitmen organisasi, komitmen organisasi berpengaruh positif dan signifikan terhadap kinerja karyawan, pengawasan berpengaruh positif dan signifikan terhadap kinerja karyawan motivasi kerja tidak berpengaruh positif dan signifikan terhadap kinerja karyawa, dan komunikasi interpersonal memiliki pengaruh positif dan signifikan terhadap kinerja karyawan.

\section{Pengaruh Pengawasan dan Komunikasi terhadap Kinerja}

Dari persamaan regresi $\mathrm{Y}=0,274+$ $0,865 \mathrm{X}_{1}+0,141 \mathrm{X}_{2}$ menggunakan nilai konstanta sebesar a $=0,274$ menyatakan bahwa jika Pengawasan $\left(\mathrm{X}_{1}\right)$ dan Komunikasi $\left(\mathrm{X}_{2}\right)$ tidak ada perubahan atau nilainya nol maka nilai variabel Kinerja (Y) adalah sebesar 0,274.

Koefesien regresi Pengawasan $\left(\mathrm{X}_{1}\right)$ sebesar $b_{1}=0,865$ menyatakan bahwa setiap peningkatan Pengawasan $\left(\mathrm{X}_{1}\right)$ sebesar satu satuan maka hal tersebut akan 
meningkatkan kinerja (Y) sebesar 0,865.

Dengan demikian juga sebaliknya jika ada penurunan Pengawasan $\left(\mathrm{X}_{1}\right)$ sebesar satu satuan maka hal tersebut akan menurunkan kinerja (Y) sebesar 0,865.

Koefesien regresi Komunikasi $\left(\mathrm{X}_{2}\right)$ sebesar $b_{2}=0,141$ menyatakan bahwa setiap peningkatan Komunikasi $\left(\mathrm{X}_{2}\right)$ sebesar satu satuan maka hal tersebut akan meningkatkan kinerja (Y) sebesar 0,141. Dengan demikian juga sebaliknya jika ada penurunan Komunikasi $\left(\mathrm{X}_{2}\right)$ sebesar satu satuan maka hal tersebut akan menurunkan kinerja (Y) sebesar 0,141

Nilai koefesien determinasi di peroleh angka $R$ square $\left(R^{2}\right)$ sebesar 0,960 atau $96,0 \%$. Nilai tersebut memberikan pengertian bahwa Pengawasan $\left(\mathrm{X}_{1}\right)$ dan Komunikasi $\left(\mathrm{X}_{2}\right)$ memberiakan sumbangan pengaruh 96,0\% terhadap Kinerja (Y). Sedangkan sisanya $4,0 \%$ dipengaruhi variabel lain yang tidak termasuk dalam penelitian ini.

Berdasarkan nilai $F_{\text {hitung }}$ yang diperoleh adalah sebesar 291,566 dengan tingkat signifikansi 0,000. Dimana jika $F_{\text {hitung }}>$ $\mathrm{F}_{\text {tabel }}$ maka Ho di tolak dan Ha diterima. Sebaliknya jika $F_{\text {hitung }}<\mathrm{F}_{\text {tabel }}$ maka Ho diterima dan Ha ditolak. Pada penelitian ini ternayata $F_{\text {hitung }}(291,566)>F_{\text {tabel }}(3,18)$, artinya Ho ditolak dan Ha diterima. Hal ini menunjukkan ada pengaruh yang signifikan antara variabel Pengawasan ( X1) dan variabel Komunikasi (X2) terhadap Kinerja (Y).

Hipotesis ketiga yang menyatakan bahwa terdapat pengaruh signifikan secara bersama-sama antara Pengawasan $\left(\mathrm{X}_{1}\right)$ dan Komunikasi $\left(\mathrm{X}_{2}\right)$ berpengaruh positif terhadap Kinerja (Y). Berdasarkan hasil pengolahan data, nilai $F_{\text {hitung }}$ adalah 291,566 dan nilai $F_{\text {tabel }}$ adalah 3,18. Dari data tersebut terlihat bahwa $\mathrm{F}_{\text {hitung }}$ lebih besar $\mathrm{F}_{\text {tabel }}\left(\mathrm{F}_{\text {hitung }}>\mathrm{F}_{\text {tabel }}\right)$. Maka dapat disimpulkan secara simultan variabel Pengawasan (X1) dan variabel Komunikasi
(X2) berpengaruh signifikan positif terhadap Kinerja (Y).

Selanjutnya hasil penelitian ini didukung oleh penelitian yang dilakukan oleh Rocmad Fajar Darmanto (2018) yang mengemukakan bahwa variabel Pengawasan (X1) terbukti memiliki pengaruh yang kuat terhadap variabel Kinerja (Y) yaitu sebesar 0,297. Variabel Komunikasi (X2) terbukti memiliki pengaruh yang kuat terhadap variabel Kinerja (Y) yaitu sebesar 0,287. Variabel Motivasi Kerja (X3) terbukti mempunyai pengaruh yang kuat terhadap variabel Kinerja (Y) yaitu sebesar 0,445. Secara simultan atau bersama-sama terdapat pengaruh positif antara variabel Pengawasan (X1), variabel Komunikasi (X2), dan variabel Motivasi Kerja (X3) terhadap variabel Kinerja (Y), dengan perolehan nilai sebesar 0,588 atau $58,8 \%$. Sehingga dapat disimpulkan bahwa peningkatan kerja 58,8\% dipengaruhi oleh variabel Pengawasan, variabel Komunikasi dan variabel Motivasi Kerja.

Kemudian didukung penelitian dari Dinda Shara Harum Febriani (2018) yang menyatakan bahwa Metode yang digunakan ialah analisis regeresi berganda. Teknik analisis data menggunakan uji reabilitas, uji validitas, uji asumsi klasik, uji koefesien determinasi, uji $\mathrm{F}$, uji $\mathrm{t}$, dan uji tunggal untuk menguji efek mediasi. Diperoleh nilai koefesien determinasi $\left(\mathrm{R}^{2}\right)$ sebesar 0,585 yang berrati bahwa $58,5 \%$ variasi dari komitmen organisasi dapat dijelaskan oleh variabel pengawasan, motivasi kerja, dan komunikasi interpersonal. Sedangkan sisanya sebesar $41,5 \%$ dapat diejlaskan oleh variabel lain diluar penelitian ini. Selanjutnya, nilai $\mathrm{F}$ pada struktur I yaitu 24,038 dengan tingkat signifikansi 0,000, dan pada struktur II yaitu 17,467 dengan tingkat signifikansi 0,000 . Hasil penelitian ini menunjukkan bahwa pengawasan memiliki pengaruh positif dan dampak signifikan terhadap komitmen organisasi, 
motivasi kerja berpengaruh positif dan signifikan berdampak pada komitmen organisasi, komunikasi interpersonal berpengaruh positif dan signifikan berdampak pada komitmen organisasi, komitmen organisasi berpengaruh positif dan signifikan terhadap kinerja karyawan, pengawasan berpengaruh positif dan signifikan terhadap kinerja karyawan motivasi kerja tidak berpengaruh positif dan signifikan terhadap kinerja karyawa, dan komunikasi interpersonal memiliki pengaruh positif dan signifikan terhadap kinerja karyawan.

\section{KESIMPULAN}

Berdasarkan penelitian dari analisis sesuai dengan rumusan masalah penelitian, maka peneliti dapat menyimpulkan bahwa:

1. Hasil perhitungan uji $t$ diketahui hasil $t_{\text {hitung }}$ menunjukkan bahwa variabel Pengawasan $\left(\mathrm{X}_{1}\right)$ mempunyai nilai $\mathrm{t}_{\text {hitung }}$ sebesar 22,830 lebih besar dibandingkan dengan nilai $t_{\text {tabel }}$ pada taraf nyata sebesar 1,675. Jumlah sampel 53 ditemukan df $=(53-2)$ dan taraf signifikansi sebesar 0,05. Dari data tersebut terdapat bahwa $t_{\text {hitung }}$ lebih besar dari $t_{\text {tabel }}$ ( $t_{\text {hitung }}>t_{\text {tabel }}$ ) maka dapat dikatakan bahwa variabel Pengawasan $\left(\mathrm{X}_{1}\right)$ berpengaruh signifikan terhadap Kinerja (Y).

2. Hasil perhitungan uji t diketahui hasil $t_{\text {hitung }}$ menunjukkan bahwa variabel Komunikasi $\left(\mathrm{X}_{2}\right)$ mempunyai nilai $\mathrm{t}_{\text {hitung }}$ sebesar 8,178 lebih besar dibandingkan dengan nilai $t_{\text {tabel }}$ pada taraf nyata sebesar 1,675. Jumlah sampel 53 ditemukan df $=(53-2)$ dan taraf signifikansi sebesar 0,05. Dari data tersebut terdapat bahwa $t_{\text {hitung }}$ lebih besar dari $\mathrm{t}_{\text {tabel }}$ ( $\mathrm{t}_{\text {hitung }}>\mathrm{t}_{\text {tabel }}$ ) maka dapat dikatakan bahwa variabel Komunikasi $\left(\mathrm{X}_{2}\right)$ berpengaruh signifikan terhadap Kinerja (Y).

3. Hasil perhitungan Anova (Uji f), terlihat bahwa nilai $F_{\text {hitung }}$ yang diperoleh adalah sebesar 291,566 dengan tingkat signifikansi 0,000. Dimana jika $F_{\text {hitung }}>F_{\text {tabel }}$ maka Ho di tolak dan Ha diterima. Sebaliknya jika $\mathrm{F}_{\text {hitung }}<\mathrm{F}_{\text {tabel }}$ maka Ho diterima dan $\mathrm{Ha}$ ditolak. Pada penelitian ini ternayata $F_{\text {hitung }}$ $(291,566)>F_{\text {tabel }}(3,18)$, artinya Ho ditolak dan Ha diterima. Hal ini menunjukkan ada pengaruh yang signifikan antara variabel Pengawasan (X1) dan variabel Komunikasi (X2) terhadap Kinerja (Y).

\section{SARAN}

Dari hasil kesimpulan yang telah diambil sebelumnya, dapat diajukan beberapa saran :

1. Dari hasil analisis di ketahui bahwa pengawasan meiliki hubungan yang sangat kuat dan komunikasi memiliki hubungan yang kuat terhadap kinerja pegawai Dinas Pendidikan Kabupaten Musi Rawas, hal ini perlu mendapat perhatian khusus organisasi, khusunya bagi pimpinan agar dapat melakukan tugas dengan sebaik mungkin, dalam hal ini adalah dengan melakukan pengawasan secara rutin dan terjadwal terhadap aktivitas kerja pegawai dan juga menciptakan komunikasi yang efektif baik antara pimpinan dengan pegawai, pegawai dengan pimpinan maupun antar sesama pegawai.

2. Berdasarkan analisis pula diketahui bahwa pengawasan merupakan variabel yang berpengaruh dominan terhadap kinerja pegawai Dinas Pendidikan Kabupaten Musi Rawas. Berarti pengawasan merupakan salah satu yang sangat pentig bagi kinerja pegawai, seyogyanya pimpinan harus terus memberikan pengawasan yang rutin terhadap pegawai agar pegawai dapat melakukan pekerjaan dengan maksimal sesuai dengan arahan pimpinan dan SOP organisasi.

\section{DAFTAR PUSTAKA}

[1] Bangun, Wilson. 2012. Manajemen Sumber Daya Manusia. Jakarta: PT Gelora Aksara Pratama. 
[2] Bintaro dan Daryanto. 2017. Manajemen Penilaian Kinerja Karyawan. Cetakan ke I. Yogyakarta: Gava Media.

[3] Busro, Muhammad. 2018. Teori-teori Manajemen Sumber Daya Manusia. Cetakan ke 1. Jakarta: Prenadamedia Group.

[4] Cangara, Hafied. 2014. Pengantar Ilmu Komunikasi. Cetakan ke XIV. Jakarta :Rajawali Pers.

[5] Fahmi, Irham. 2016. Manajemen Sumber Daya Manusia. Cetakan Ke I. Bandung: Alfabeta.

[6] Fahmi, Irham. 2017. Manajemen Sumber Daya Manusia. Cetakan Ke II. Bandung: Alfabeta.

[7] Ghozali, Imam. 2018. Aplikasi Analisis Multivariate dengan Program IBM SPSS 25. Cetakan Ke IX. Semarang: Badan Penerbit-Undip.

[8] Handoko, T.H. 2015. Manajemen Edisi 2. Yogyakarta: BPFE.

[9] Kasmir. 2016. Manajemen Sumber Daya Manusia. Cetakan Ke II. Jakarta :Rajawali Pers.

[10] Mangkunegara, Prabu, Anwar. 2017. Manajemen Sumber Daya Manusia Perusahaan. Cetakan Ke I. Bandung: PT Remaja Rosdakara.

[11] Muhammad, Arni. 2015. Komunikasi Organisasi. Cetakan Ke XIV. Jakarta: PT Bumi Aksara.

[12] Mulyana, Deddy. 2011. Ilmu Komunikasi. Cetakan Ke XV. Bandung: PT Remaja Rosdakarya.

$\begin{array}{rrrr}\text { [13] Nurhasanah, } & \text { Nunung. } & \text { 2010. Ilmu } \\ \text { Komunikasi } & \text { dalam } & \text { Konteks }\end{array}$
Keperawatan. Cetakan Ke I. Jakarta: Trans Info Media.

[14] Silalahi, Uber. 2015. Asas-Asas Manajemen. Cetakan Ke III. Bandung: PT Refika Aditama.

[15] Sugiyono. 2013. Metode Penelitian Bisnis. Cetakan Ke XVII. Bandung: Alfabeta.

[16] Sugiyono. 2018. Metode Penelitian Manajemen. Cetakan Ke VI. Bandung: Alfabeta.

[17] Sujarweni, Wiratna, V. 2015. Metode Penelitian Bisnin dan Ekonomi. Cetakan Ke 1. Yogyakarta: Pustaka Baru Press.

[18] Sutrisno, Edy. 2016. Manajemen Sumber daya Manusia. Cetakan Ke VIII. Jakarta: Prenada Media Group.

[19] Wibowo. 2014. Manajemen Kinerja. Cetakan Ke IV. Jakarta: Rajawali Pers.

[20] Wibowo. 2016. Manajemen Kinerja. Cetakan Ke XI. Jakarta: Rajawali Pers. 